\title{
手間なく、手早く、手際よく高分解能構造を 手に入れるためのビームライン技術開発
}

\author{
○平田 邦生 \\ (理研 SPring-8 センター)
}

大型放射光施設 SPring-8 の理研ターゲ ットタンパクビームライン BL32XU の運 用開始から 8 年が経過した。ユーザ実験 に貢献するためのビームライン技術開発 はタイトルにある目標を持って継続して いる。

ビームライン立ち上げ当初から 2 3 年 は、それまでデータ収集が困難であった 小さな結晶からいかに高分解能データ収 集を実現するかを目指して研究開発を行 った。確立したデータ収集プロトコルを 手早く行う高速スキャンシステム、結晶 検出ソフトウェアの整備も行った。

2015 年には、それまでの経験に基づい た実験プロトコルを自動化し、自動デー タ収集システム ZOO のプロトタイプの 完成に至った。2018 年現在、人間が行う であろう測定スキームすべて ZOO で実 行することが可能である。結晶を凍結し てユニパックにつめ、実験条件を入力し てZOO を実行すれば手間なく手際よく データ収集を完了することができる。

特に最近実装した「Mixed mode」とい う測定方法では、大きな面積のホルダー 上に複数マウントされた結晶のサイズや 空間的な配置に基づいてそれぞれの結晶 に最適な測定スキームを自動的に選定し 測定を進める (HITO システム)。これに よって測定者は結晶を拾って凍結する場 合に、一つの結晶を一つのホルダーに拾 い上げて凍結せずとも結晶の体積を最大
限活用したデータ収集が可能である。

HITO システムの開発と並行して次に 設定したテーマは、LCP 法で得られた結 晶をいかに手間なくビームラインへ持ち 込むか、ということであった。LCP 法で 得られる結晶は条件によってそれを取り 巻く脂質の粘度が異なる（主にキュービ ック相とスポンジ相)。とりわけ現時点で 主流なガラスサンドイッチ法ではウェル のガラスをまず割って結晶をすくう必要 がある。さらに、スポンジ相結晶の場合 には脂質の粘性が低く、ガラスを慎重に 割り、結晶をすくうがループから結晶が 逃げ、初心者がストレスなくすくうこと はまず不可能である。熟練度にも依存す るが結晶の $20 \%$ 程度しか回収できない場 合もある。

そこで Molecular Dimensions 社から市 販されているガラスサンドイッチを模し たフィルムサンドイッチ (Diffrax ${ }^{\mathrm{TM}}$ plate) による結晶化、切り出し工程、新しい試 料ホルダーの試作、凍結方法、測定方法 について検討を重ね、手間なくより多く の結晶からデータ収集を実現することを 目指している。

ビームライン測定技術開発の現状とい くつかの成功例、困難な点などを発表し よりよい開発に向けた議論を行って頂き たいと考えている。 